\title{
Erratum to: Identification of a restriction point at the M/G1 transition in $\mathrm{CHO}$ cells
}

\author{
E. Hulleman ${ }^{1,2}$ J. J. M. Bijvelt ${ }^{1}$ A. J. Verkleij ${ }^{1}$ C. T. Verrips ${ }^{1} \cdot$ J. Boonstra $^{1}$
}

Published online: 5 June 2017

(C) Springer International Publishing 2017

Erratum to: CMLS, Cell. Mol. Life Sci. 61 (2004) 600-609

DOI 10.1007/s00018-003-3360-9

In the original publication, the first author's name was incorrectly published as E. Hullemann in the electronic version. The correct name should read as E. Hulleman in both online and print versions.

The online version of the original article can be found under doi:10.1007/s00018-003-3360-9.

\section{J. Boonstra}

j.boonstra@bio.uu.nl

1 Department of Molecular Cell Biology, Utrecht University, Padualaan 8, $3584 \mathrm{CH}$ Utrecht, The Netherlands

2 Department of Experimental Oncology, European Institute of Oncology, via Ripamonti 435, 20141 Milan, Italy 